\title{
Substance Use and Abuse Among Older Adults: A State of the Art
}

\author{
Marja Aartsen \\ VU-University Amsterdam \\ The Netherlands
}

\section{Introduction}

Substance abuse, defined here as the abuse of alcohol, cannabis, cocaine and heroin, in older adults is often neglected, both in science and in practice. Substance abuse is a serious public health issue as it not only affects physical and mental health of the abusers, it also leads to increased costs for society (Adams et al., 1993). Older adults with addiction problems deserve special attention. Compared to younger people, smaller amounts of substance may lead to intoxication and organ damage because of greater use of contraindicated medications, less efficient liver metabolism and decreases in lean body mass and total body water (Dufour \& Fuller, 1995).

Substance use and abuse among people aged 50 and over is rapidly increasing in Europe and the United States (Beynon, 2009). For Europe, the number of older people with substance use problems is estimated to more than double between 2001 and 2020 (Gossop, 2008). This is partly due to the size of the baby-boom cohort (born between 1946 and 1964) and the higher rate of substance use among this group (Gfroerer et al., 2003). Estimates from the United States suggest that the number of adults aged 50 and over will double from 2.8 million (annual average) in 2002-06 to 5.7 million in 2020 (Han et al., 2009).

To reduce the negative trend in substance abuse, effective prevention is required. Cuijpers and Willemse (2005) distinguish four types of prevention in this context; universal prevention, selective prevention, indicated prevention and care based prevention. For each level of prevention, specific knowledge is needed. For universal prevention, targeted at the entire population regardless of the risk of addiction, knowledge about the prevalence, causes and adverse consequences of risk-full use are important. In selective prevention, aimed at groups at risk of becoming addicted, knowledge of risk factors is essential to identify the groups. For indicated prevention, aimed at people with limited symptoms, it is important to recognize signs of addiction and have knowledge of appropriate treatments. Finally, care based prevention, referring to people with an addiction according to DSM criteria, it is important to have insight into factors that influence the course of the disease. Insufficient knowledge of one or more levels of prevention can lead to under-recognition of addiction problems by social workers (Adams et al., 1992), lack of agreement between doctors on the causes and treatment of addiction (Brown, 1982), and people are still insufficiently aware of the importance and effects of proper treatment (McInnes \& Powell, 1994). 
In this chapter, an overview is given of what is known about the prevalence and the biopsycho-social characteristics of older people who abuse substances. In addition, we will describe the known risk factors for the development and course of substance abuse.

\section{Methods}

\subsection{Review}

In addressing the aim of this chapter, three databases (PubMed, PsychINFO, and Socindex) were investigated for potentially relevant studies using the following keywords: "Alcohol", "drug abuse", "heroin", "cocaine", "cannabis", "substance abuse" each combined with AND (elderly OR older adults). Based on the title and abstract of each retrieved article the potential relevance for the current study was investigated. We selected only articles that were written in English, have appeared in peer-reviewed journals, were based on original quantitative empirical research, aiming at the older population (aged 50 years or older). Relevant information for answering the research questions was extracted from each selected article. For information on the prevalence and the bio-psycho-social characteristics of older people who abuse substances, studies containing information on one or more of the following characteristics were selected: prevalence, trends in use with age, bio-psycho-social characteristics of users, and risk-full use or addiction. For information on risk factors for the development and course of substance abuse, only longitudinal studies or case-control studies were selected.

\subsection{Definitions}

Substance abuse is defined in accord with the Diagnostic and Statistical Manual of Mental Disorders (DSM) if three or more of the following criteria were met: 1) tolerance, as defined by either a need for markedly increased amounts of the substance to achieve intoxication or the desired effect or markedly diminished effect with continued use of the same amount of the substance; 2) withdrawal, as manifested by the characteristic withdrawal syndrome for the substance or the same (or closely related) substance is taken to relieve or avoid withdrawal symptoms; 3 ) the substance is often taken in larger amounts or over a longer period than intended; 4) there is a persistent desire or unsuccessful efforts to cut down or control substance use; 5) a great deal of time is spent in activities necessary to obtain the substance, use the substance, or recover from its effects; 6) important social, occupational, or recreational activities are given up or reduced because of substance use; and 7) the substance use is continued despite knowledge of having a persistent physical or psychological problem that is likely to have been caused or exacerbated by the substance.

A limitation of the DSM classification is that it does not take account of the specific circumstances and life stage in which older people reside. The consequences of substance abuse are more visible in people who are still employed than in people who live alone, which is more prevalent among older people. Also milder forms of abuse or risky use can significantly affect the physical, cognitive and mental health of older adults. Therefore, also risk-full substance use will be addressed in this study.

\section{Results}

The literature search resulted in 432 studies potentially relevant to this investigation. Based on the title and abstract 81 studies were subsequently selected for further study and 
data extraction. Of the 81 selected studies, 75 studies were on alcohol consumption, 7 studies on alcohol use in combination with medicines and one study on cocaine and heroin use. Only a small fraction of all studies $(n=10)$ focused on addiction according to DSM-IV criteria. The results will be summarized around 6 themes: recognition of alcohol abuse, prevalence, changes in substance use with aging, bio-psycho-social characteristics of older substance users, risk factors, and consequences of abuse. In addition, also study results for risk-full of alcohol that does not fit the DSM criteria for an addiction will be summarized. The results will be described separately for alcohol, cannabis, heroin and cocaine.

\subsection{Recognition of alcohol abuse}

Assessing correct diagnosis regarding alcohol abuse is complicated (Aartsen et al., 2009). This is partly due to the reluctance of abusers and health care practitioners to discuss the drinking behavior. However, even without explicitly asking, there are signs that may indicate an underlying alcohol problem. For example, in some cases the breath of people can smell like alcohol, there may be complaints from the social environment of people about alcohol consumption, there may be convictions for driving with to much previous alcohol intake, and people may become annoyed once the subject is brought up to alcohol. Also, certain physical problems may indicate alcohol problems, such as hypertension, gastrointestinal problems, unexplained falls and psychological symptoms as anxiety and depression. There are screening instruments especially developed for older people that can help professionals to make a more deliberated diagnose. A simple, but not always adequate way is to ask how much alcohol is consumed on average per day. Besides the danger of under-reporting (people tend to underestimate their own drinking behavior), the average number of drinks per day is not always informative. Whether you drink two glasses a day, or once a week, 14 units, the average remains the same, but the social and physical consequences can vary widely. Moreover, one factor that affects the harmful effects of alcohol intake is the fat-moisture balance, and whether there are any concurrent medications or other chronic diseases that does not tolerate alcohol intake. A good alternative is the Alcohol Related Problem Survey (ARPS: Fink et al., 2002). The ARPS is a comprehensive questionnaire which not only questions drinking behavior, but also assesses health, life style, drug use and risky behaviors such as driving after alcohol use. Other screenings instruments are the Alcohol Use Disorders Identification Test (AUDIT), the Short Michigan Alcohol Screening Test-Geriatric (SMAST-G) and the Cut down, Annoyed, Guilty, Eyeopener test (CAGE).

\subsection{Prevalence of substance use and abuse}

Prevalence of risk-full alcohol consumption in the community ranged from 3 to $22 \%$ in men and 1 to $4 \%$ in women (Table 1). Men are two to five times more often risk-full alcohol consumers. The number of cannabis, heroin and cocaine users in the U.S. population is low (Blazer \& Wu, 2009), of which the use of cannabis was the most prevalent. The annual prevalence of cannabis for people aged 50-64 year was 3,9\%, and for people aged $650.7 \%$. The annual prevalence of cocaine use by $50-64$ year olds and $65+$ was, respectively $0.68 \%$ and $0.04 \%$. Heroin was used by $0.08 \%$ of $50-64$ year old people. Heroin use is not observed among people aged 65 and over. 
Prevalence rates of substance abuse, however, should be taken with caution. Taking into account that substance abuse among older adults is often under-diagnosed (Stewart \& Oslin, 2001), and given the fact that only a small fraction of those with disorders related to substance abuse seek treatment, the actual number of older people with an alcohol use disorder in the general population must be much higher.

\begin{tabular}{|c|c|c|}
\hline $\begin{array}{l}\text { Alcohol } \\
\text { First author } \\
\text { and year of } \\
\text { publication }\end{array}$ & & Country \\
\hline Breslow 2003 & $\begin{array}{l}\text { Prevalence of heavy drinking ranged from } 9 \text { to } 10 \% \text { in men } \\
\text { and from } 2 \% \text { to } 3 \% \text { in women }\end{array}$ & US \\
\hline Merrick 2008 & $16 \%$ of the men and $4 \%$ of the women are risk-full users & US \\
\hline Du 2009 & $\begin{array}{l}15 \% \text { risk-full drinking, and } 8 \% \text { benzodiazepine and alcohol } \\
\text { use }\end{array}$ & $\mathrm{DE}$ \\
\hline Ganry 2001 & $3 \%$ of the $75+$ women drank more than 30 grams per day & FR \\
\hline Halme 2009 & $\begin{array}{l}20 \% \text { of the men and } 1 \% \text { of the women are heavy drinkers } \\
\text { (more than } 8 \text { standard glasses per week) }\end{array}$ & FI \\
\hline La Greca 1988 & $6 \%$ heavy users & US \\
\hline Lang 2007 & $22 \%$ of the men and $4 \%$ of the women are heavy drinkers & GB \\
\hline Rodgers 2005 & $\begin{array}{l}7 \% \text { of the men and } 6 \% \text { of the women drink hazardous } \\
\text { amounts of alcohol }\end{array}$ & AU \\
\hline Mirand 1996 & $13 \%$ of the men and $2 \%$ women were heavy drinkers & US \\
\hline \multicolumn{3}{|c|}{ Cannabis, Cocaine, Heroin } \\
\hline Blazer 2009 & $\begin{array}{l}\text { Prevalence of cannabis use: 3,9\% for people aged 50-64 } \\
\text { Prevalence of cannabis use: } 0,7 \% 65 \text { year old people } \\
\text { Prevalence of cocaine use: } 0,7 \% \text { for people aged } 50-64 \\
\text { Prevalence of cocaine use: } 0,04 \% \text { for } 65 \text { year old } \\
\text { Prevalence of heroin use: } 0,08 \% \text { for people aged } 50-64 \\
\text { Prevalence of heroin use: } 0,0 \% 65 \text { year old people }\end{array}$ & US \\
\hline
\end{tabular}

Table 1. Prevalence of alcohol, cannabis, cocaine and heroin use in society

In patient populations, prevalence rates of alcohol use were higher (Table 2). Estimates of the incidence of risk-full drinking range from $2 \%$ in women to $17 \%$ in men. Alcohol addiction in France varies in different patient populations from 3\% in women and 18\% in men (Lejoyeaux et al., 2003). Also Speckens et al., (1991) found high prevalence of alcohol in a university hospital in the Netherlands.

\subsection{Developments in alcohol use with aging}

Trends in alcohol use with aging were estimated in a number of longitudinal studies. Research in the United States (Adams et al., 1990) shows that older people generally reduce the number of drinks as they become older (each year a decrease of $2 \%$ drinkers). There is an indication for a gender effect. Men who drink heavily, but continue to drink, reduce drinking as opposed to heavily drinking women whose alcohol consumption remained stable (Breslow et al., 2003). 


\begin{tabular}{|c|c|c|}
\hline $\begin{array}{l}\text { First author } \\
\text { and year of } \\
\text { publication }\end{array}$ & & Country \\
\hline Adams 1992 & $\begin{array}{l}\text { Prevalence of lifetime alcohol abuse: } 24 \% \\
\text { Prevalence of current alcohol abuse: } 14 \% \text {. }\end{array}$ & US \\
\hline Blow 2000 & Prevalence of risk-full drinkers: $7 \%$ & US \\
\hline Kahn 2001 & $\begin{array}{l}\text { Prevalence of risk-full alcohol use: } 5 \% \text {. } \\
\text { Prevalence of lifetime alcohol abuse: men 37\%, women } 12 \% \text {. } \\
\text { Prevalence for last year alcohol abuse: } 0.5 \%\end{array}$ & $\mathrm{NZ}$ \\
\hline Ganry 2000 & Prevalence of risk-full alcohol use: men $17 \%$, women $3 \%$ & FR \\
\hline Kirchner 2007 & Prevalence of risk-full drinkers: $5 \%$ & US \\
\hline Lawley 1996 & $\begin{array}{l}\text { Prevalence of risk-full use: } 12 \% \\
\text { Prevalence of abuse: } 3 \%\end{array}$ & GB \\
\hline Lejoyeux 2003 & Prevalence of alcohol abuse: $18 \%$ men and $3 \%$ women & FR \\
\hline Onen 2005 & Prevalence in Emergency Departments of alcohol abuse: 5,3\% & $\mathrm{BE}$ \\
\hline Speckens 1991 & Prevalence of alcohol abuse: men $13 \%$, women $7 \%$ women & NL \\
\hline
\end{tabular}

Table 2. Prevalence of alcohol abuse in patient population

\subsection{Bio-psycho-social characteristics of older substance users \\ 3.4.1 Alcohol}

Older adults who are addicted to alcohol constitute a heterogeneous group consisting of people who have been addicted to alcohol before the age of 25 (early onset), people whose addiction started between the 25th and 45th year of life (late onset), and people who could remain at moderate levels of drinking till the age of 45 , and became addicted at higher ages (very late onset). It is currently believed that the etiology and the course of alcohol disorders or risk-full drinking is complex and includes both genetic and environmental factors and the interaction of the two (Edenberg \& Foroud, 2006). Genetic factors leading to differential risk for alcoholism were demonstrated using twin and family studies. In addition, functional polymorphisms of alcohol dehydrogenase (ADH2) and aldehyde dehydrogenase (ALDH2) genes have been shown to have a significant impact on alcohol metabolism in the liver, and thus, may contribute to vulnerability to alcohol abuse and dependence (Yokoyama \& Omori, 2003). Antisocial personality is found to be a frequent cause of early onset (Watson et al., 1997), whereas very late onset seems to be more often induced by stressful life events (Hurt, 1988). Furthermore, early onset is more often seen among people who are homeless, who have family members with alcohol problems, and who have low socio-economic status, and people with very late onset often show better social functioning, have normal family lives and professional careers, rarely have a criminal history; furthermore, the course of very late onset is more favorable compared to early onset or late onset (Liberto \& Oslin, 1995; Rigler, 2000).

Studies consistently show that there is a U-shaped relationship between alcohol use and mental and physical health. Abstainers, high-risk users and addicts have a poorer physical and mental health than moderate users (Blow et al., 2000; Brideveaux et al., 2004, Mukamal et al., 2001; Rodgers et al., 2005). Alcohol use appears to be related to prevailing beliefs about alcohol (Akers et al., 1989, Preston \& Goodfellow, 2006; Graham \& Braun, 1999). 
Catholics, white people and non religious people drink significantly more than other ethnic groups or religions (Breslow et al., 2003; Forster et al., 1993, Merrick et al., 2008; Ruchlin, 1997). Higher education is associated with more, but also risk-full alcohol use (Breslow et al., 2003, Forster et al., 1993; Goodwin et al., 1987; Merrick et al., 2008; Ruchlin, 1997). Alcohol consumers smoke more than non-users (Mirand \& Welte, 1996; Ganry et al., 2001), and alcoholics often live alone (Brennan, 2005; Onen et al., 2002).

\begin{tabular}{ll}
\hline First author & Main findings \\
\hline Adlaf 1995 & Men report more alcohol related problems then women \\
Aira 2005 & Most alcohol drinkers used medications on a regular basis
\end{tabular}
$(86.9 \%)$ or as needed $(87.8 \%)$.

Akers 1989 Drinking is related to the norms and behavior of one's primary groups, one's own attitudes toward (definitions of) alcohol, and the balance of reinforcement for drinking

Blow 2000 Low-risk drinkers were significantly better off than abstainers on the following domains: general health, physical functioning, bodily pain, vitality, mental health, emotional role, and social functioning. At-risk drinkers had significantly poorer mental health functioning than low-risk drinkers.

Brennan 2005

Nursing home residents with alcohol use disorders were more likely to have lived alone before admission and to have obtained mental health and social services. Residents with alcohol use disorders had somewhat better performance of basic activities than did residents in the demographically-matched sample group. Men with alcohol use disorders had shorter lengths of stay than did men without alcohol use disorders; women with alcohol use disorders had longer lengths of stay than did women without such disorders.

Breslow 2003 White people had the highest prevalence of moderate and heavier drinking compared with other racial/ethnic groups. Higher education was related to higher drinking levels. Moderate drinking was related to living with a partner.

Brideveaux 2004 Drinkers have a better health status than nondrinkers. Problem drinkers had lower health status than drinkers without drinking problems

Christie 2008

Controlling for age, gender, and vascular health, global Cerebral Blood Flow was greater in the lightest alcohol consumption group ( $<1$ per week) and lower in the heaviest ( $>15$ per week).

Forster 1993 Drinking is related to male gender, higher education, Catholic or no organized religious affiliation.

Ganry 2001

Gao 2009 Smoking, good health status, higher socioeconomic status or single marital status are related to higher levels of alcohol use.

Moderate current and lifetime alcohol consumption were found to be associated with reduced chronic atrophic arthritis compared to alcohol.

Geroldi 1994

Male gender, poorer cognitive function, and income dissatisfaction were significantly associated with alcohol problems. 


\begin{tabular}{ll}
\hline First author & Main findings \\
\hline Goodwin 1987 & Alcohol intake was positively associated with male gender, \\
& income, cognitive functioning and amount of education and \\
& negatively associated with age.
\end{tabular}

Graham \& Schmidt 1999 Depression was correlated with heavier drinking.

Graham \& Braun 1999 Having a drinking spouse (versus an abstinent spouse) was associated with higher levels of drinking.

Kirchner 2007

Heavy drinking showed significant positive association with depressive/anxiety symptoms and less social support. Heavy drinking combined with binging was similarly positively associated with depressive/anxiety symptoms and perceived poor health.

Lang 2007

For both men and women, better cognition and subjective wellbeing, and fewer depressive symptoms, were associated with moderate levels of alcohol consumption than with never having drunk any.

Mattace-Raso 2005

Moderate alcohol consumption is associated with lower arterial stiffness in women but not in men independently of cardiovascular risk factors and atherosclerosis

Merrick 2008 Unhealthy drinking Is associated with higher education and income; better health status; male sex; younger age; smoking; being white; and being divorced, separated, or single. were associated with higher likelihood of unhealthy drinking.

Among drinkers, in addition to socio-demographic variables, self reported depressive symptoms were positively associated with unhealthy drinking.

Among unhealthy drinkers, race and ethnicity variables were associated with likelihood of heavy episodic drinking.

Midanik 1992 Sense of Coherence was a significant negative predictor of alcohol problems while controlling for alcohol consumption level, frequency of drunkenness and demographic characteristics.

Mirand 1996 Positive associations between heavy drinking and being male, having suburban residency, and currently using cigarettes. Negative relationships between heavy drinking and socioeconomic status, rural residency, and degree of health orientation.

Mukamal 2001

Moderate alcohol consumption is associated with a lower prevalence of white matter abnormalities and infarcts, thought to be of vascular origin, but with a dose-dependent higher prevalence of brain atrophy on MRI among older adults.

Mukamal 2004

Alcohol intake is associated with lower levels of inflammatory markers in older adults free of cardiovascular disease

Musick 2000

Alcohol use had no effect on depressive symptoms. One exception to this latter finding was that among rural Baptists who rarely attended religious services, using alcohol was associated with more depressive symptoms. 


\begin{tabular}{|c|c|}
\hline First author & Main findings \\
\hline Onen 2002 & $\begin{array}{l}\text { Being homeless, living alone, being divorced and never married and } \\
\text { being a man was associated with alcohol use disorders. Drinkers } \\
\text { more commonly presented with gastrointestinal disorders. }\end{array}$ \\
\hline Oslin 2005 & $\begin{array}{l}\text { Among people with alcohol use disorders, } 22,3 \% \text { has current } \\
\text { depressive disorder, } 44,9 \text { physical disabilities, } 13,6 \text { anxiety disorder, } \\
70,8 \% \text { have college or higher education, } 57 \% \text { married. Compared to } \\
\text { younger patients, they have less mental health problems, less severe } \\
\text { alcohol use, and less outpatient treatment experience. }\end{array}$ \\
\hline Preston 2006 & $\begin{array}{l}\text { Frequency of drinking and abuse is positively associated with } \\
\text { personal approval of daily alcohol use and number of peers who } \\
\text { use alcohol. }\end{array}$ \\
\hline Rapuri 2000 & $\begin{array}{l}\text { Moderate alcohol intake was associated with higher bone } \\
\text { mineral density in postmenopausal elderly women. }\end{array}$ \\
\hline Rice 1995 & $\begin{array}{l}\text { Alcohol consumption was negatively associated with General } \\
\text { Practitioners visits, controlling for gender and health }\end{array}$ \\
\hline Riserus 2007 & $\begin{array}{l}\text { In men: self-estimated alcohol intake was not related to insulin } \\
\text { sensitivity, early insulin response, or BMI, but was positively } \\
\text { related to Waist Circumference. }\end{array}$ \\
\hline Rodgers 2005 & Abstainers have poorer cognitive function than light drinkers. \\
\hline Ruchlin 1997 & $\begin{array}{l}\text { Everyday drinkers are more likely to being male, white, higher } \\
\text { educated, living in the city centre and less likely to be in less } \\
\text { than in excellent health, having diabetes, and believing that } \\
\text { drinking has negative health consequences. }\end{array}$ \\
\hline Schuckit 1978 & $\begin{array}{l}\text { Compared to younger alcoholics, older alcoholics had relatively } \\
\text { more stable lives in early years and had developed alcohol- } \\
\text { related problems in later years }\end{array}$ \\
\hline Sheahan 1995 & Alcohol use is not related to falls \\
\hline Steunenberg 2008 & $\begin{array}{l}\text { Depression and alcohol use are not related in this very old, } \\
\text { mostly female population. Alcohol use was related to } \\
\text { extraversion and openness to experience. Chronic diseases was } \\
\text { related to non-alcohol use and parental problem drinking was } \\
\text { found to be a risk factor for late life problem drinking. }\end{array}$ \\
\hline Sulander 2004 & $\begin{array}{l}\text { Higher alcohol use was more common among retired office } \\
\text { workers than other former employees. }\end{array}$ \\
\hline Westerterp 2004 & $\begin{array}{l}\text { Alcohol intake does not lead to increased body weight, probably } \\
\text { due to the higher physical activity level }\end{array}$ \\
\hline
\end{tabular}

Table 3. Bio-Psycho-Social chraracteristics of older people who (ab)use alcohol

The relationship between cognitive functioning, cognitive pathology and drinking is more complicated. Risk-full use seems to be associated with worse cognitive function (Geroldi et al., 1994) and moderate use with better cognitive function (Goodwin et al., 1987; Lang et al., 2007; Rodgers et al., 2005). There are indications that the relationship is actually spurious, as the relation disappears when controlling for other potential influences (Cooper et al., 2009; Goodwin et al., 1987).

Several studies found a relationship with physical characteristics. Women who drink moderate levels of alcohol have a higher density of mineral in bone (Ilich et al., 2002; Rapuri et al., 2000). A positive correlation between alcohol use, reduced inflammation, lower prevalence of strokes 
and white matter pathology, and the quality of blood vessels is found by Christie et al. (2008), Gao et al.(2009), Mattace-Raso et al. (2005) and Mukamal et al. (2001, 2004).

Risk-full drinkers appear to be more often depressed (Blow et al., 2000, Graham \& Schmidt, 1999; Oslin et al., 2005), while moderate drinkers have fewer levels of depressive symptoms (Blow et al., 2000, Graham \& Schmidt, 1999; Kirchner et al., 2007; Lang et al., 2007, Merrick et al, 2008). A relationship between alcohol and depression was however not found in very old nursing home residents (Steunenberg et al., 2008) and older Baptists (Musick, 2000).

\subsubsection{Cannabis, cocaine and heroin}

One study reported information on older cannabis, cocaine and heroin users. These users are more often male, single, and have depressive symptoms, but no differences in educational background are observed (Blazer \& Wu, 2009).

\subsection{Risk factors for substance abuse}

Only one longitudinal study examined risk factors for risk-full drinking (Moos et al., 2010). The study revealed that a lower quality of marriage, lower participation in social activities, approval of drinking by friends and larger financial resources lead to an increased risk of risky alcohol use.

\subsection{Consequences of substance use}

In general, moderate consumption of alcohol has beneficial effects on physical and mental health, while risk-full use entails negative effects. Moderate alcohol use leads to higher bone density (Felson et al., 1995), longer life (Brideveaux et al., 2004; Colditz et al., 1985; Simons et al., 2000;), and reduced risk of Type 2 Diabetes (Djousse et al., 2007). Moderate alcohol consumption may also have some negative consequences as it may increase blood pressure, glycemia and body weight (Buja et al., 2010). Risk-full alcohol use leads to an increased risk of mental health problems (Friedman et al., 1999) and mortality (Gronbaek et al., 1998) and possibly an increased risk of acute pneumonia (Van der Horst Graat et al., 2007).

\section{Conclusions}

This study provides an overview of scientific knowledge in the field of substance abuse (alcohol, cannabis, heroin, and cocaine) in people aged 55 and older. Three databases were searched for relevant literature. There is useful information on alcohol use and risk-full use, but large gaps in knowledge about substance abuse exists. Research on alcohol addiction is limited and use of cannabis, cocaine and heroin in older adults is virtually absent. Moreover, many of the studies had a cross-sectional design, which limits conclusions about causes and effects. An additional problem is that most of the studies were conducted in the United States, while that information not necessarily applies to other countries because of cultural differences is (Vaz De Almeida et al., 2005).

Nevertheless, an outline of people who use risk-full amounts of alcohol became visible. First, there is a U-shaped relationship between amount of alcohol use and health. Moderate users are healthier than high-risk users and abstainers. The fact that abstainers were worse of than moderate users is possibly explained on the basis of the great heterogeneity in the non-using group. Not drinking is associated with certain medications and thus indicates the presence of disease, previous alcohol dependence, but also a healthy lifestyle. 
High-risk alcohol users were more often male (2-5 times more), live in social environments where alcohol is not condemned, are higher educated, smoke more often, are more often single or depressed and may have poorer cognitive function. With age, the average consumption of alcohol decreases, except for risk-full drinking women. The consequences of risk-full alcohol use are decreased mental health and increased mortality. Very little is known about causes of alcohol addiction.

For information about use of cannabis, heroin and cocaine in older adults, we can only rely on one study conducted in the US. Of the three, cannabis is most often used, particularly 50 64 year olds (year prevalence $3.89 \%$ and $0.69 \%$ at 65 ). Less than 1 percent of older people use cocaine, while heroin use is not seen in people over 65 (Blazer \& $\mathrm{Wu}, 2009$ ).

In sum, it appears that knowledge of substance abuse in older adults is still mainly limited to the description of bio-psycho-social characteristics of older adults with alcohol abuse. Knowledge of prevalence, causes, consequences and characteristics of the elderly who according to DSM criteria are addicted to any of the tested agents is still virtually absent. The design of effective prevention of substance abuse in older adults, as well as effective therapies is therefore strongly hampered. With respect to universal and selective prevention at the population level, more research is required into causes and consequences of substance abuse. For effective care-oriented prevention research into the effects of treatments in patients populations such as in addiction clinics is needed in order to improve the effect of treatment programs.

\section{Acknowledgements}

The literature review was supported by The Netherlands Organization for Scientific Research NWO/ZonMW (project number 31160205).

\section{References}

Aartsen, M., Van Etten, D. \& Spitsbaard, A. (2009). Older people and substance abuse [Ouderen en verslavingsproblematiek]. In: Addiction, handbook for care, support and prevention, Rutten, R., Loth, C. \& Hulshof, A., pp.255-267, Elseviers gezondheidszorg, ISBN 978903523071 2, Maarssen, The Netherlands.

Adams, W. L., Garry, P. J., Rhyne, R., Hunt, W. C., \& Goodwin, J. S. (1990). Alcohol intake in the healthy elderly. Changes with age in a cross-sectional and longitudinal study. J.Am.Geriatr.Soc., 38, 211-216.

Adams, W. L., Magruder-Habib, K., Trued, S., \& Broome, H. L. (1992). Alcohol abuse in elderly emergency department patients. J.Am.Geriatr.Soc., 40, 1236-1240.

Adams, W. L., Yuan, Z., Barboriak, J. J., \& Rimm, A. A. (1993). Alcohol-related hospitalizations of elderly people. Prevalence and geographic variation in the United States. JAMA, 270, 1222-1225.

Adlaf, E. M. \& Smart, R. G. (1995). Alcohol use, drug use, and well-being in older adults in Toronto. Int.J.Addict., 30, 1985-2016.

Aira, M., Hartikainen, S., \& Sulkava, R. (2005). Community prevalence of alcohol use and concomitant use of medication. A source of possible risk in the elderly aged 75 and older? Int.J.Geriatr.Psychiatry, 20, 680-685.

Akers, R. L., La Greca, A. J., Cochran, J., \& Sellers, C. (1989). Social learning theory and alcohol behavior among the elderly. The Sociological Quarterly, 30, 625-638. 
Blazer, D. G. \& Wu, L. T. (2009). The epidemiology of substance use and disorders among middle aged and elderly community adults: national survey on drug use and health. Am.J.Geriatr.Psychiatry, 17, 237-245.

Blow, F. C., Walton, M. A., Barry, K. L., Coyne, J. C., Mudd, S. A., \& Copeland, L. A. (2000). The relationship between alcohol problems and health functioning of older adults in primary care settings. J.Am.Geriatr.Soc., 48, 769-774.

Brennan, P. L. (2005). Functioning and health service use among elderly nursing home residents with alcohol use disorders: findings from the National Nursing Home Survey. Am.J.Geriatr.Psychiatry, 13, 475-483.

Breslow, R. A., Faden, V. B., \& Smothers, B. (2003). Alcohol consumption by elderly Americans. J.Stud.Alcohol, 64, 884-892.

Bridevaux, I. P., Bradley, K. A., Bryson, C. L., McDonell, M. B., \& Fihn, S. D. (2004). Alcohol screening results in elderly male veterans: association with health status and mortality. J.Am.Geriatr.Soc., 52, 1510-1517.

Brown, B. B. (1982). Professionals' perceptions of drug and alcohol abuse among the elderly. Gerontologist, 22, 519-525.

Buja, A., Scafato, E., Sergi, G., Maggi, S., Suhad, M. A., Rausa, G. et al. (2010). Alcohol consumption and metabolic syndrome in the elderly: results from the Italian longitudinal study on aging. Eur.J.Clin.Nutr., 64, 297-307.

Christie, I. C., Price, J., Edwards, L., Muldoon, M., Meltzer, C. C., \& Jennings, J. R. (2008). Alcohol consumption and cerebral blood flow among older adults. Alcohol, 42, 269275.

Colditz, G. A., Branch, L. G., Lipnick, R. J., Willett, W. C., Rosner, B., Posner, B. et al. (1985). Moderate alcohol and decreased cardiovascular mortality in an elderly cohort. Am.Heart J., 109, 886-889.

Cooper, C., Bebbington, P., Meltzer, H., Jenkins, R., Brugha, T., Lindesay, J. E. et al. (2009). Alcohol in moderation, premorbid intelligence and cognition in older adults: results from the Psychiatric Morbidity Survey. J.Neurol.Neurosurg.Psychiatry, 80, 1236-1239.

Cuijpers, P., \& Willemse, G. (2005) Preventie van depressie bij ouderen: Een overzicht van interventies. Trimbos Instituut, Utrecht 2005.

Djousse, L., Biggs, M. L., Mukamal, K. J., \& Siscovick, D. S. (2007). Alcohol consumption and type 2 diabetes among older adults: the Cardiovascular Health Study. Obesity.(Silver.Spring), 15, 1758-1765.

Du, Y., Scheidt-Nave, C., \& Knopf, H. (2008). Use of psychotropic drugs and alcohol among non-institutionalised elderly adults in Germany. Pharmacopsychiatry, 41, 242-251.

Dufour, M \& Fuller, R.K. (1995) Alcohol in the elderly. Annual Review of Medicine, 46, 123132

Edenberg, H.J. \& Foroud, T. (2006). The genetics of alcohol disorder: Identifying specific genes through family studies. Addiction Biology, 11, 386-396.

Felson, D. T., Zhang, Y., Hannan, M. T., Kannel, W. B., \& Kiel, D. P. (1995). Alcohol intake and bone mineral density in elderly men and women. The Framingham Study. Am.J.Epidemiol., 142, 485-492.

Fink, A., Morton, S.C., Beck, J.C., e.a. (2002). The alcohol-related problems survey: Identifying hazardous and harmful drinking in older primary care patients. Journal of American Geriatrics Society, 50, 1717-1722. 
Forster, L. E., Pollow, R., \& Stoller, E. P. (1993). Alcohol use and potential risk for alcoholrelated adverse drug reactions among community-based elderly. Journal of Community Health, 18, 225-239.

Friedmann, P. D., Jin, L., Karrison, T., Nerney, M., Hayley, D. C., Mulliken, R. et al. (1999). The effect of alcohol abuse on the health status of older adults seen in the emergency department. Am.J.Drug Alcohol Abuse, 25, 529-542.

Ganry, O., Joly, J. P., Queval, M. P., \& Dubreuil, A. (2000). Prevalence of alcohol problems among elderly patients in a university hospital. Addiction, 95, 107-113.

Ganry, O., Baudoin, C., Fardellone, P., \& Dubreuil, A. (2001). Alcohol consumption by noninstitutionalised elderly women: the EPIDOS Study. Public Health, 115, 186-191.

Gao, L., Weck, M. N., Stegmaier, C., Rothenbacher, D., \& Brenner, H. (2009). Alcohol consumption and chronic atrophic gastritis: population-based study among 9,444 older adults from Germany. Int.J.Cancer, 125, 2918-2922.

Geroldi, C., Rozzini, R., Frisoni, G. B., \& Trabucchi, M. (1994). Assessment of alcohol consumption and alcoholism in the elderly. Alcohol, 11, 513-516.

Gfroerer, J., Penne, M., Pemberton, M., \& Folson, R. (2003). Substance abuse treatment need among older adults in 2020. The impact of the aging baby-boom cohort. Drug and Alcohol Dependence, 69, 127-135.

Goodwin, J. S., Sanchez, C. J., Thomas, P., Hunt, C., Garry, P. J., \& Goodwin, J. M. (1987). Alcohol intake in a healthy elderly population. Am.J.Public Health, 77, 173-177.

Gossop, M (2008) Substance Use among Older Adults: A Neglected Problem. Lisbon: European Monitoring Centre for Drugs and Drug Addiction; 2008. Available from http://www.emcdda.europa.eu/attachements.cfm/att_50566_EN_TDAD08001EN C_web.pdf

Graham, K. \& Schmidt, G. (1999). Alcohol use and psychosocial well-being among older adults. J.Stud.Alcohol, 60, 345-351.

Graham, K. \& Braun, K. (1999). Concordance of use of alcohol and other substances among older adult couples. Addictive Behaviors, 24, 839-856.

Gronbaek, M., Deis, A., Becker, U., Hein, H. O., Schnohr, P., Jensen, G. et al. (1998). Alcohol and mortality: is there a U-shaped relation in elderly people? Age Ageing, 27, 739744.

Halme, J. T., Seppa, K., Alho, H., Poikolainen, K., Pirkola, S., \& Aalto, M. (2010). Alcohol consumption and all-cause mortality among elderly in Finland. Drug Alcohol Depend., 106, 212-218.

Han, B, Gfroerer, J.C., Colliver, J.D. \& Penne, M.A. (2009) Substance use disorder among older adults in the United States in 2020. Addiction, 104, 88-96

Hurt, R.D., Finlayson, R.E. Morse, R.M., \& Davis, L.J. (1988), Alcoholism in elderly persons: Medical aspects and prognosis of 216 inpatients, in: Mayo Clinic Procedures, 63, 8, 761768.

Ilich, J. Z., Brownbill, R. A., Tamborini, L., \& Crncevic-Orlic, Z. (2002). To drink or not to drink: how are alcohol, caffeine and past smoking related to bone mineral density in elderly women? J.Am.Coll.Nutr., 21, 536-544.

Khan, N., Wilkinson, T. J., Sellman, J. D., \& Graham, P. (2001). Patterns of alcohol use and misuse among elderly rest home residents in Christchurch. N.Z.Med.J., 114, 58-61.

Kirchner, J. E., Zubritsky, C., Cody, M., Coakley, E., Chen, H., Ware, J. H. et al. (2007). Alcohol consumption among older adults in primary care. J.Gen.Intern.Med., 22, $92-$ 97. 
La Greca, A., Akers, R. L., \& Dwyer, J. W. (1988). Life events and alcohol behavior among older adults. Gerontologist, 28, 552-558.

Lang, I., Wallace, R. B., Huppert, F. A., \& Melzer, D. (2007). Moderate alcohol consumption in older adults is associated with better cognition and well-being than abstinence. Age Ageing, 36, 256-261.

Lawley, D. I., Reham, H., \& Kendrick, D. (1996). The misuse of alcohol in elderly psychiatric patients. Psychiatric Bulletin, 20, 310.

Liberto, J.G. \& Oslin, D.W. (1995). Early versus late onset alcohol disorder in the elderly. International Journal of Addiction, 30, 1799-1818.

Lejoyeux, M., Delaroque, F., McLoughlin, M., \& Ades, J. (2003). Alcohol dependence among elderly French inpatients. Am.J.Geriatr.Psychiatry, 11, 360-364.

Mattace-Raso, F. U., van der Cammen, T. J., van den Elzen, A. P., Schalekamp, M. A., Asmar, R., Reneman, R. S. et al. (2005). Moderate alcohol consumption is associated with reduced arterial stiffness in older adults: the Rotterdam study. J.Gerontol.A Biol.Sci.Med.Sci., 60, 1479-1483.

McInnes, E. \& Powell, J. (1994). Drug and alcohol referrals: are elderly substance abuse diagnoses and referrals being missed? BMJ, 308, 444-446.

Merrick, E., Horgan, C. M., Hodgkin, D., Garnick, D. W., Houghton, S. F., Panas, L. et al. (2008). Unhealthy Drinking Patterns in Older Adults: Prevalence and Associated Characteristics. Journal of American Geriatrics Society, 56, 214-223.

Midanik, L. T., Soghikian, K., Ransom, L. J., \& Polen, M. R. (1992). Alcohol problems and sense of coherence among older adults. Soc.Sci.Med., 34, 43-48.

Mirand, A. L. \& Welte, J. W. (1996). Alcohol consumption among the elderly in a general population, Erie County, New York. Am.J.Public Health, 86, 978-984.

Moos, R. H., Brennan, P. L., Schutte, K. K., \& Moos, B. S. (2010). Social and financial resources and high-risk alcohol consumption among older adults. Alcohol Clin.Exp.Res., 34, 646-654.

Mukamal, K. J., Longstreth, W. T., Jr., Mittleman, M. A., Crum, R. M., \& Siscovick, D. S. (2001). Alcohol consumption and subclinical findings on magnetic resonance imaging of the brain in older adults: the cardiovascular health study. Stroke, 32, 1939-1946.

Mukamal, K. J., Cushman, M., Mittleman, M. A., Tracy, R. P., \& Siscovick, D. S. (2004). Alcohol consumption and inflammatory markers in older adults: the Cardiovascular Health Study. Atherosclerosis, 173, 79-87.

Mukamal, K. J., Chung, H., Jenny, N. S., Kuller, L. H., Longstreth, W. T., Jr., Mittleman, M. A. et al. (2005). Alcohol use and risk of ischemic stroke among older adults: the cardiovascular health study. Stroke, 36, 1830-1834.

Musick, M. A. (2000). Religious Activity, Alcohol Use, and Depression in a Sample of Elderly Baptists. Research on Aging, 22, 91.

Onen, S.H., Onen, F., Mangeon, J. P., Abidi, H., Courpron, P., \& Schmidt, J. (2005). Alcohol abuse and dependence in elderly emergency department patients. Archives of Gerontology and Geriatrics, 41, 191-200.

Oslin, D. W., Slaymaker, V. J., Blow, F. C., Owen, P. L., \& Colleran, C. (2005). Treatment outcomes for alcohol dependence among middle-aged and older adults. Addict.Behav., 30, 1431-1436.

Preston, P. \& Goodfellow, M. (2006). Cohort comparisons: social learning explanations for alcohol use among adolescents and older adults. Addict.Behav., 31, 2268-2283. 
Rapuri, P. B., Gallagher, J. C., Balhorn, K. E., \& Ryschon, K. L. (2000). Alcohol intake and bone metabolism in elderly women. Am.J.Clin.Nutr., 72, 1206-1213.

Rice, C. \& Duncan, D. F. (1995). Alcohol use and reported physician visits in older adults. Preventive Medicine, 24, 229-234.

Rigler, S.K. (2000), Alcoholism in the elderly. American Family Physician 61, 1710-1725.

Riserus, U. \& Ingelson, E. (2007). Alcohol intake, insulin resistance, and abdominal obesity in elderly men. Obesity, 15, 1766-1773.

Rodgers, B., Windsor, T. D., Anstey, K. J., Dear, K. B., Jorm, F., \& Christensen, H. (2005). Non-linear relationships between cognitive function and alcohol consumption in young, middle-aged and older adults: the PATH Through Life Project. Addiction, 100, 1280-1290.

Ruchlin, H. S. (1997). Prevalence and correlates of alcohol use among older adults. Prev.Med., 26, 651-657.

Schuckit, M. A., Morrissey, E. R., \& O'Leary, M. R. (1978). Alcohol problems in elderly men and women. Addictive Diseases, 3, 405-416.

Sheahan, S. L., Coons, S. J., Robbins, C. A., \& Martin, S. S. (1995). Psychoactive medication, alcohol use, and falls among older adults. Journal of Behavioral Medicine, 18, 127-140.

Simons, L. A., McCallum, J., Friedlander, Y., Ortiz, M., \& Simons, J. (2000). Moderate alcohol intake is associated with survival in the elderly: the Dubbo Study. Med.J.Aust., 173, 121-124.

Speckens, A. E., Heeren, T. J., \& Rooijmans, H. G. (1991). Alcohol abuse among elderly patients in a general hospital as identified by the Munich Alcoholism Test. Acta Psychiatr.Scand., 83, 460-462.

Steunenberg, B., Yagmur, S., \& Cuijpers, P. (2008). Depression and alcohol use among the Dutch residential home elderly: Is there a shared vulnerability? Addiction Research $\mathcal{E}$ Theory, 16, 514-525.

Stewart, D., \& Oslin, D.W. (2001). Recognition and treatment of late-life addictions in medical settings. Journal of Clinical Geropsychology, 7, 145-158.

Sulander, T., Helakorpi, S., Rahkonen, O., Nissinen, A., \& Uutela, A. (2004). Smoking and alcohol consumption among the elderly: trends and associations, 1985-2001. Prev.Med., 39, 413-418.

Van der Horst Graat JM, Terpstra, J. S., Kok, F. J., \& Schouten, E. G. (2007). Alcohol, smoking, and physical activity related to respiratory infections in elderly people. J.Nutr.Health Aging, 11, 80-85.

Vaz De Almeida, M. D., Davidson, K., De Morais, C., Marshall, H., Bofill, S., Grunert, K. G. et al. (2005). Alcohol consumption in elderly people across European countries: Results from the food in later life project. Ageing International, 30, 377-395.

Watson, C.G., Hancock,M.B.A., Gearhart, L.P.M., Malovrh, P., Mendez, C.B.S. \& Raden, M.B.A (1997). A comparison of the symptoms associated with early and late onset alcohol dependence. The Journal of Nervous and Mental Disease, 185, 507-509.

Westerterp, K.R., Meijer, E.P., Goris, A.H.C., \& Kester, A.D.M. (2004). Alcohol energy intake and habital physical activity in older adults. British Journal of Nutrition, 91, 149-152. 


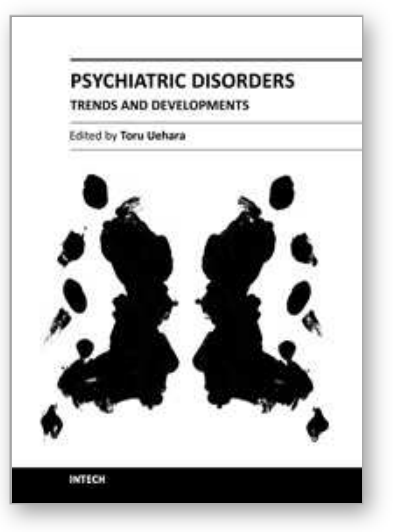

\author{
Psychiatric Disorders - Trends and Developments \\ Edited by Dr. Toru Uehara
}

ISBN 978-953-307-745-1

Hard cover, 514 pages

Publisher InTech

Published online 26, October, 2011

Published in print edition October, 2011

Due to their prevalence, pervasiveness and burden inflicted on men and women of today, psychiatric disorders are considered as one of the most important, sever and painful illnesses. This impairment of cognitive, emotional, or behavioural functioning is in some cases tragic. Aside from knowing the physical organic factors, such as infections, endocrinal illnesses or head injuries, the aetiology of psychiatric disorders has remained a mystery. However, recent advances in psychiatry and neuroscience have been successful in discovering subsequent pathophysiology and reaching associated bio-psycho-social factors. This book consists of recent trends and developments in psychiatry from all over the world, presented in the form of multifarious and comprehensive articles. The first two sections of the book are reserved for articles on schizophrenia and depression, two major illnesses present in this field. The third section of the book is reserved for addiction psychiatry, related not only to socio-cultural but also biological alterations. The last section of the book, titled Biological Neuropsychiatry, consists of three topics - updated molecular biology, fundamental neuroscience and clinical neuropsychiatric conditions. Doubtlessly, this book will be fruitful for future developments and collaboration in world psychiatry.

\title{
How to reference
}

In order to correctly reference this scholarly work, feel free to copy and paste the following:

Marja Aartsen (2011). Substance Use and Abuse Among Older Adults: A State of the Art, Psychiatric Disorders - Trends and Developments, Dr. Toru Uehara (Ed.), ISBN: 978-953-307-745-1, InTech, Available from: http://www.intechopen.com/books/psychiatric-disorders-trends-and-developments/substance-use-and-abuseamong-older-adults-a-state-of-the-art

\section{INTECH}

open science | open minds

\section{InTech Europe}

University Campus STeP Ri

Slavka Krautzeka 83/A

51000 Rijeka, Croatia

Phone: +385 (51) 770447

Fax: +385 (51) 686166

www.intechopen.com

\section{InTech China}

Unit 405, Office Block, Hotel Equatorial Shanghai

No.65, Yan An Road (West), Shanghai, 200040, China

中国上海市延安西路65号上海国际贵都大饭店办公楼 405 单元

Phone: +86-21-62489820

Fax: +86-21-62489821 
(C) 2011 The Author(s). Licensee IntechOpen. This is an open access article distributed under the terms of the Creative Commons Attribution 3.0 License, which permits unrestricted use, distribution, and reproduction in any medium, provided the original work is properly cited. 